\title{
CXCL2 wt Allele
}

National Cancer Institute

\section{Source}

National Cancer Institute. CXCL2 wt Allele. NCI Thesaurus. Code C49764.

Human CXCL2 wild-type allele is located within $4 \mathrm{q} 21$ and is approximately $2 \mathrm{~kb}$ in length. This allele, which encodes C-X-C motif chemokine 2 protein, is involved in tissue-specific regulation. 